\title{
Assessment of Scapular Morphometry
}

\author{
Evaluación de la Morfometría Escapular
}

Neslihan Boyan"; Esin Ozsahin²; Emine Kizilkanat'; Roger W. Soames ${ }^{3}$ \& Ozkan Oguz ${ }^{1}$

BOYAN, N.; OZSAHIN, E.; KIZILKANAT, E.; SOAMES, R. W. \& OGUZ, O. Assessment of scapular morphometry. Int. J. Morphol., 36(4):1305-1309, 2018.

SUMMARY: The current study was undertaken to assess the incidence of different types of suprascapular notch, acromion dimensions and the lower and upper scapular angles. The suprascapular notch and variations of the acromion are clinically important in suprascapular nerve compression and subacromial impingement. Measurements were taken from 73 Anatolian dry scapulae of unknown age or sex. The suprascapuar notch was classified according to that of Rengachary et al. (1979). Its width and depth, the distance between supraglenoid tubercle and the deepest point of notch, as well as the upper and lower scapular angles were also determine measured. The type of acromion was assessed according to shape (type I (cobra), type II (square), type III (intermediate)) and tilt (type I (flat), type II (curve). Acrmion length and the distance between acromion and coracoid process were also measured. The frequency of different types of suprascapular notch were type I (28.8 \%), type II (23.3 \%), type III (13.7 \%), type IV (20.5 \%), type V (2.7 \%), type VI (5.5\%)and absence (5.5\%). Acromion type were type I (45.5\%), type II (7.5\%) and type III (47.0\%), acromion tilt type I (15.2 \%), and type II (84.8 \%). An understanding of the association between the anatomical structures of the scapula and morphometric measurements is clinically important.

KEY WORDS: Suprascapular notch; Acromion; Scapular morphometry.

\section{INTRODUCTION}

Scapulae have a complex anatomy due to their spesific irregular shape. This flat, triangular bone has two surfaces (costal and dorsal), three margins (superior, lateral and medial), three angles (superior, inferior and lateral) and three bony projections (spine, acromion and coracoid process). It is a major component of the pectoral girdle playing an important role in the varied and complex movements of the upper limb. It articulates with the clavicle and humerus forming the shoulder complex. The three bony projections give attachment to a number of muscles and ligaments (Romanes, 1995; Soames, 1995). Clinical changes associated with the various projections may modify the biomechanics of the upper limb. Anomalies of the shoulder joint, including fractures, dislocations, arthritis, inflammatory and pathological conditions may also arise. Many surgical approaches, such as arthroplasty, glenohumeral arthrodesis, internal fixation for the stabilization of fractures, acromioplasty and acromionectomy for rotator cuff tendinitis all involve the scapula. A detailed knowledge of scapular anatomy is therefore essential for successful total shoulder arthroplasty or surgical treatment of disorders related to scapula and shoulder, as well as shoulder arthroscopy (Ebraheim et al., 2000; von Schroeder et al., 2001). Furthermore, a clear understanding of the morphology of the acromion, glenoid fossa, coracoid process and subacromial space is necessary to alleviate shoulder pain and rotator cuff insufficiency (Aktan et al., 1996; Getz et al., 1996; Taskinalp et al., 2001). The cause of subacromial syndrome is compression of the soft tissues (rotator cuff muscles and subacromial bursae) in the subacromial space by the head of the humerus, acromion, coracoacromial ligament and coracoid process (Ertem et al., 1990; Romanes; Aktan et al.; Unal et al., 1997; Ebraheim et al.; Taskınalp et al.; von Schroeder et al.). Morphometric studies on the subacromial space have confirmed the importance of this region.

The variations of the suprascapular notch (SN) have clinical significance for suprascapular impingement syndrome, while the determination of acromion type is

\footnotetext{
${ }^{1}$ Cukurova University, Faculty of Medicine, Department of Anatomy, Adana, Turkey.

${ }^{2}$ Baskent University Faculty of Medicine, Department of Anatomy, Adana, Turkey.

${ }^{3}$ Centre for Anatomy and Human Identification, School of Science and Engineering, University of Dundee, Dundee, DD1 5EH, UK.

PS: This manuscript was presented as a poster presentation at the IVth International Symposium of Clinical and Applied Anatomy (ISCAA), Ankara/ Turkey, $28^{\text {th }}$ June $-1^{\text {st }}$ July, 2012.
} 
important in shoulder impingement (Aydinlioglu. et al., 1997; Prescher, 2000). Rengachary et al. (1979) reported six distinct types of SN (Urguden et al. 2004): it can be turned into a foramen by ossification of the transverse ligament of the scapula. The foramen then serves as a conduit for the suprascapular nerve, which gives sensory branches to ligamentous structures associated with the acromioclavicular and shoulder joints and motor branches to supraspinatus and infraspinatus (Aydinlioglu et al.; Bayramoglu et al., 2003; Urguden et al., 2004; Sabanciogullari et al., 2006; Ofusori et al., 2008). In some cases variation of the transverse ligament accompany NS variations: these may play a role in entrapment neuropathies. Injury to the suprascapular nerve may result in loss of function of the rotator cuff muscles (Aydinlioglu et al.; Ticker et al., 1998; Urguden et al., 2004; Sabanciogullari et al.; Ofusori et al.).

The acromion partly covers the humeral head: it articulates with the clavicle and gives attachment to the anterolateral portion of deltoid and coracoacromial ligament. Its association with chronic pain and shoulder dysfunction has been observed (Voisin et al., 2014; Nyffeler \& Meyer, 2017). The morphometry of the acromion process is important as it is related to pectoral girdle pathologies (Saha \& Vasudeva, 2017). Investigations into acromial morphology have largely been restricted to its shape and tilt (Natsis et al., 2007). Nevertheless, it has been classified into three different types: type I, flat; type II, curved; type III, hooked (Bigliani et al., 1986; MacGillivray et al., 1998; Mayerhoefer et al., 2005; Natsis et al.). Type I is most common, while types II and III are considered important factors in the development of subacromial impingement syndrome (Mayerhoefer et al. 2005). There is a significant association between aspects of acromial morphology and rotatory cuff ruptures, as well as subacromial impingement syndrome, commonly observed in orthopedic examination (Mayerhoefer et al., 2005).

This current study was conducted to determine the clinical importance of scapular morphometry, particularly of the suprascapular notch and acromion, and its variations.

\section{MATERIAL AND METHOD}

Seventy three intact adult scapulae of unknown age and sex from the anatomy laboratory of Cukurova University Medical Faculty were selected and examined. The suprascapular notch $(\mathrm{SN})$ was classified according to the definition of Rengachary et al. (Fig. 1): its width and depth, the distance from the supraglenoid tubercle to its deepest point were determind (Fig. 2). In addition, acromial length and the distance from the acromion to the coracoid process was also determined (Fig. 2). The angle between the lateral margin of the $\mathrm{SN}$, the superior angle and root of the spine was measured and considered as the upper scapular angle (USA), while the angle between root of the spine, the inferior angle and infraglenoid tubercle was measured and considered as the lower scapular angle (LSA) (Fig. 2). The shape of the acromion was assessed as being type I (cobra), type II (square) and type III (intermediate) (Fig. 3) and its tilt as type I (flat) or type II (curved) (Fig. 4).

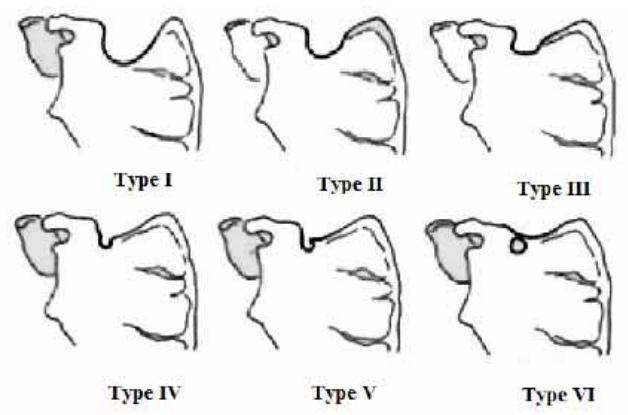

Fig. 1. Types of suprascapular notch: adapted from Rengachary et al. (1979).

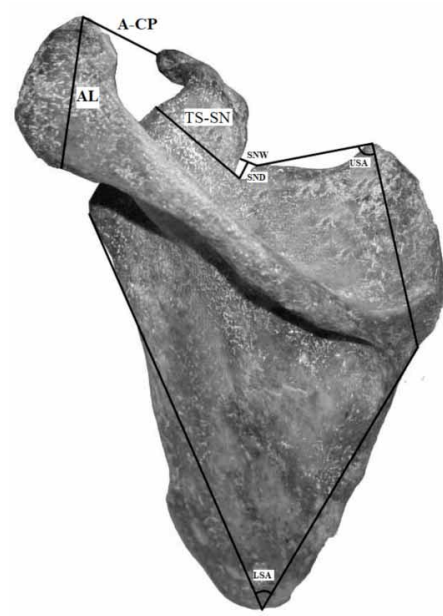

Fig. 2. Morphometric measurements of the scapula. SNW, suprascapular notch width; SND, suprascapular notch depth; TS-SN, distance between the supraglenoid tubercle and deepest point of the suprascapular notch AL; acromion length; A-CP, distance between the acromion and coracoid process; USA, upper scapular angle; LSA; lower scapular angle.

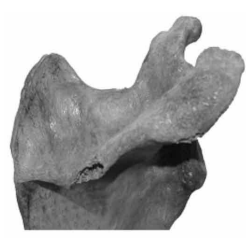

Type I

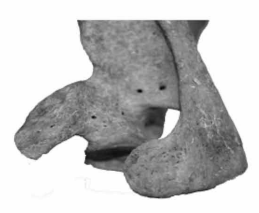

Type II

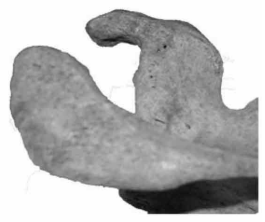

Tpye III
Fig. 3. Type of acromion according to shape. Type I; cobra, Type II, square; Tpye III; intermediate. 

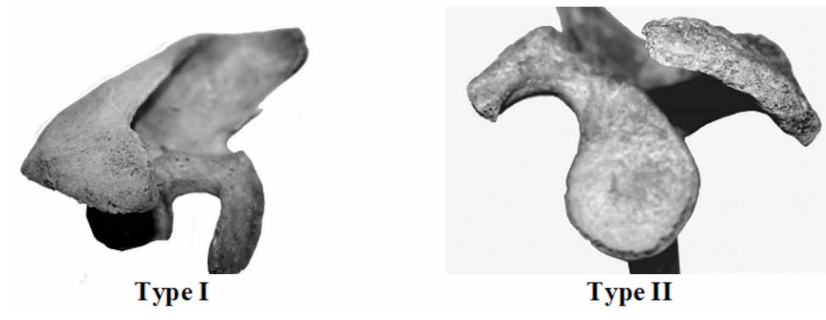

Fig. 4.Type of acromion according to tilt. Type I; flat, Type II; hooked.

\section{RESULTS}

Table I shows the linear measurements and angles associated with different SN types. The SN types observed were; as type I (28.8 \%), type II (23.3\%), type III (13.7\%), type IV $(20.5 \%)$, type V (2.7\%), type VI (5.5\%): a notch was absence in $5.5 \%$ of specimens (Table I). According to its shape the acromion the majority were type III (47.0\%), closely followed by type I $(45.5 \%)$ and then type II $(7.5 \%)$ (Table II), while according to tilt $84.8 \%$ were type II and $15.2 \%$ type I (Table III). The associated measurements for each type of acromion are also presented in Tables II and III.

\section{DISCUSSION}

For shoulder arthroscopy the distance of certain structures from palpable bone landmarks is vital to determine entrance points. The suprascapular nerve can be injured during arthroscopy associated with the suprascapular notch (von Schroeder et al.). Taser \& Basaloglu (2003) demonstrated significant differences between sexes in the distance between the edge of coracoid process and the suprascapular notch, while von Schroeder et al. observed that all measurements of the coracoid process were different between sexes.

Table I. Linear measurements of different types of suprascapular notch, together with the mean scapular angles.

\begin{tabular}{lccccccc}
\hline arameters & & \multicolumn{2}{c}{ Type of Suprascapular Notch } \\
& $\begin{array}{c}\text { Absent } \\
(\mathrm{n}=4 ; 5.5 \%)\end{array}$ & $\begin{array}{c}\text { Type I } \\
(\mathrm{n}=21 ; 28.8 \%)\end{array}$ & $\begin{array}{c}\text { Type II } \\
(\mathrm{n}=17 ; 23.35)\end{array}$ & $\begin{array}{c}\text { Type III } \\
(\mathrm{n}=10 ; 13.7 \%)\end{array}$ & $\begin{array}{c}\text { Type IV } \\
(\mathrm{n}=15 ; 20.5 \%)\end{array}$ & $\begin{array}{c}\text { Type V } \\
(\mathrm{n}=2 ; 2.7 \%)\end{array}$ & $\begin{array}{c}\text { Type VI } \\
(\mathrm{n}=4 ; 5.5 \%)\end{array}$ \\
\hline NW $(\mathrm{mm})$ & & 12.1 & 9.9 & 8.4 & 7.33 & 6.4 & 5.8 \\
ND $(\mathrm{mm})$ & & 6.6 & 6.8 & 7.3 & 6.22 & 5.9 & 6.2 \\
S-SN $(\mathrm{mm})$ & & 28.3 & 27.0 & 28.3 & 27.43 & 29.9 & 28.2 \\
SA $\left({ }^{\circ}\right)$ & 92.0 & 96.4 & 96.1 & 87.8 & 98.20 & 91.0 & 106.5 \\
SA $\left({ }^{\circ}\right)$ & 58.0 & 57.2 & 55.0 & 63.6 & 55.71 & 56.0 & 65.0 \\
\hline
\end{tabular}

SN, suprascapular notch; SNW, suprascapular notch width; SND, suprascapular notch depth; TS-SN, distance from the supraglenoid tubercle to the deepest point of the suprascapular notch; USA, upper scapular angle LSA; lower scapular angle; n, number of scapulae.

Table II. Acromion type according to shape, number of scapulae and associated acromial measurements. A-CP; distance from the acromion to the coracoid process, AL; acromion length.

\begin{tabular}{lcccc}
\hline $\begin{array}{l}\text { Type of acromion } \\
\text { according to shape }\end{array}$ & $\begin{array}{c}\text { Number of } \\
\text { scapulae }\end{array}$ & $\begin{array}{c}\text { Percentage } \\
(\%)\end{array}$ & AL (mm) & A-CP (mm) \\
\hline Type I & 30 & 45.5 & 39.71 & 42.5 \\
Type II & 5 & 7.5 & 37.4 & 34.3 \\
Type III & 31 & 47.0 & 44.8 & 34.3 \\
Total & 66 & 100 & 42.1 & 37.7 \\
\hline
\end{tabular}

Table III. Types of acromion according to tilt number of scapulae and associated acromial measurements. A-CP; distance from the acromion to the coracoid process.

\begin{tabular}{lcccc}
\hline $\begin{array}{l}\text { Types of acromion } \\
\text { according to tilt }\end{array}$ & $\begin{array}{c}\text { Number of } \\
\text { scapulae }\end{array}$ & $\begin{array}{c}\text { Type percentage } \\
(\%)\end{array}$ & $\begin{array}{c}\text { Acromion length } \\
(\mathrm{mm})\end{array}$ & $\begin{array}{c}\text { A-CP } \\
(\mathrm{mm})\end{array}$ \\
\hline Type I & 10 & 15.2 & 39.4 & 37.5 \\
Type II & 56 & 84.8 & 42.6 & 37.7 \\
Total & 66 & 100.0 & 42.1 & 37.7 \\
\hline
\end{tabular}


Rengachary et al. classified the SN into 6 distinct types. Using this classification Urgüden et al. (2004), reported that $6 \%$ of SNs were type I, $24 \%$ type II, $40 \%$ type III, $13 \%$ type IV, $11 \%$ type V and $6 \%$ type VI . Earlier Aydinlioglu et al. had reported normal SN in $64 \%$, an absent $\mathrm{SN}$ in $18 \%$, partial bridge formation in $16 \%$ and complete bridge formation in $2 \%$. In their study Sabanciogulları et al. (2006), reported the SN to be type I in $28 \%$, type II in $5.3 \%$, type III in $29.3 \%$, type IV in $14.6 \%$, type V in 13.4 $\%$ and type VI in $9.4 \%$. In contrast in the current study 28.8 $\%$ of scapulae showed type I SN, $23.3 \%$ type II, $13.7 \%$ type III, $20.5 \%$ type IV, $2.7 \%$ type V, $5.5 \%$ type VI and 5.5 $\%$ having no SN. The above suggests racial and/or ethnic differences in the type of SN present; these differences should therefore be taken into account during arthroscopic examination and surgery to avoid potential damage to the suprascapular nerve and vessels.

In the current study the lower scapular angle was $58.7^{\circ}$, the upper scapular angle was $95.5^{\circ}$, the distance between supraglenoid tubercle and SN was $28.2 \mathrm{~mm}$, SN width 8.3 $\mathrm{mm}$ and depth $6.5 \mathrm{~mm}$. Sabanciogullari et al. (2006), reported similar values from their study, being $51.2^{\circ}, 102.9^{\circ}, 26.5 \mathrm{~mm}$, $7.3 \mathrm{~mm}$ and $5.3 \mathrm{~mm}$ respectively.

In the current study the type of acromion according to shape was $45.5 \%$ type I, $7.5 \%$ type II and $47 \%$ type III, while according to tilt there were $15.2 \%$ type I and $84.8 \%$ type II. Acromion length was $42.1 \mathrm{~mm}$ and the distance between acromion and coracoid process was $37.7 \mathrm{~mm}$. Kosar et al. (2006), have reported the similar values, being $29.3 \%$, $32 \%$ and $38.7 \%$ for acromion shape, $50.7 \%$ and $41.3 \%$ for acromial tilt, and $46.1 \mathrm{~mm}$ and $29.3 \mathrm{~mm}$ for acromial length and distance between the acromion and coracoid process respectively. They have observed the hooked type of acromion (type III) in $8 \%$ of their specimens, in contrast to the current study which observed no type III acromion.

Restricted movement of the pectoral girdle and upper limb has been observed when acromial length exceeds normal values (Aktan et al.). Aktan et al. have reported that the longest acromions are the cobra type having a mean length of 50.23 \pm 7.29 , whereas Taser \& Basaloglu give a range of 41.5 to $45.3 \mathrm{~mm}$ being significantly less than Aktan et al.

Knowledge of the morphology of the adult acromion process will help define the bony landmarks to be used in assisting surgeons undertaking specific operative procedures and technique. In agreement with Saha \& Vasudeva it is concluded that the current observations in an Anatolian population combined with the findings from earlier studies will provide a more precise guide for clinicians undertaking surgical procedures involving the shoulder.
BOYAN, N.; OZSAHIN, E.; KIZILKANAT, E.; SOAMES, R. W. \& OGUZ, O. Evaluación de la morfometría escapular. Int. J. Morphol., 36(4):1305-1309, 2018.

RESUMEN: En este trabajo se evaluó la incidencia de diferentes tipos de incisura supraescapular, dimensiones de acromion y los ángulos escapulares superior e inferior. La incisura supraescapular y las variaciones del acromion son clínicamente importantes en la compresión del nervio supraescapular y el pinzamiento subacromial. Las mediciones se tomaron de 73 escápulas secas de Anatolia, de edad y sexo desconocidos. La incisura supraescapular se clasificó según Rengachary et al. (1979). Se determinaron también el ancho y la profundidad, la distancia entre el tubérculo supraglenoide y el punto más profundo de la incisura, así como los ángulos escapulares superior e inferior. El tipo de acromion se evaluó de acuerdo con la forma [tipo I (cobra), tipo II (cuadrado), tipo III (intermedio)] y la inclinación [tipo I (plano), tipo II (curvo)]. También se midieron la longitud del elemento y la distancia entre el acromion, como así también el proceso coracoide. La frecuencia de los diferentes tipos de incisura supraescapular fueron: tipo I $(28,8 \%)$, tipo II $(23,3 \%)$, tipo III $(13,7 \%)$, tipo IV $(20,5 \%)$, tipo V $(2,7 \%)$, tipo VI $(5,5 \%)$ y ausencia $(5,5 \%)$. Los tipos de acromion fueron: tipo I (45,5\%), tipo II $(7,5 \%)$ y tipo III $(47,0 \%)$, tipo de inclinación de acromion I $(15,2 \%)$ y tipo II $(84,8 \%)$. En conclusión, el conocimiento de la asociación entre las estructuras anatómicas de la escápula y las mediciones morfométricas es clínicamente importante.

PALABRAS CLAVE: Incisura supraescapular; Acromion; Morfometría escapular.

\section{REFERENCES}

Aktan, A.; Pala, S.; Tas sıran, O. \& Oztürk, L. Acromion tipleri ve uzunluk ortalamaları: Bunların dejeneratif degisiklerle iliskisi. Morfoloji Dergisi., 4(1-2):6-10, 1996.

Aydınlıoglu, A.; Diyarbakırlı, S.; Keles, P. \& Yüceer, N. Suprascapular centik degisiklikleri. Türk. Norosirurji Dergisi., 7:40-4, 1997.

Bayramoglu, A.; Demiryürek, D.; Tüccar, E.; Erbil, M.; Aldur, M. M.; Tetik, O. \& Doral, M. N. Variations in anatomy at the suprascapular notch possibly causing suprascapular nerve entrapment: an anatomical study. Knee Surg. Sports Traumatol. Arthrosc., 11(6):393-8, 2003.

Bigliani, L. U.; Morrison, D. S. \& April, E. W. The morphology of the acromion and its relationship to rotator cuff tears. Orthop. Trans., 10:228, 1986.

Ebraheim, N. A.; Xu, R.; Haman, S. P.; Meidler, J. D. \& Yeasting, R. A. Quantitative anatomy of the scapula. Am. J. Orthop. (Belle Mead N.J.), 29(4):287-92, 2000.

Getz, J. D.; Recht, M. P.; Piraino, D. W.; Schils, J. P.; Latimer, B. M.; Jellema, L. M. \& Obuchowski, N. A. Acromial morphology: relation to sex, age, symmetry, and subacromial enthesophytes. Radiology, 199(3):737-42, 1996.

Kosar, M. I.; Sabanciogullari, V.; Erdil, F. H.; Çimen, M. \& Aycan, K. Akromion tipleri ve morfometrik degerlendirmesi. Cumhur. Univ. Tip Fak. Derg., 28(1):16-20, 2006.

MacGillivray, L. D.; Fealy, S.; Potter, H. G. \& O’Brien, S. J. Multiplanar analysis of acromion morphology. Am. J. Sports Med., 26(6):83640, 1998. 
Mayerhoefer, M. E.; Breitenseher, M. J.; Roposch, A.; Treitl, C. \& Wurnig, C. Comparison of MRI and conventional radiography for assessment of acromial shape. A. J. R. Am. J. Roentgenol.,184(2):671-5, 2005.

Natsis, K.; Tsikaras, P.; Totlis, T.; Gigis, I.; Skandalakis, P.; Appell, H. J. \& Koebke, J. Correlation between the four types of acromion and the existence of enthesophytes: a study on 423 dried scapulas and review of the literature. Clin. Anat., 20(3):267-72, 2007.

Nyffeler, R. W. \& Meyer, D. C. Acromion and glenoid shape: Why are they important predictive factors for the future of our shoulders? EFORT Open Rev., 2(5):141-50, 2017.

Ofusori, D. A.; Ude, R. A.; Okwuonu, C. U. \& Adesanya, O. A. Complete absence of the suprascapular notch in a Nigerian scapula: A possible cause of suprascapular nerve entrapment. Int. J. Shoulder Surg., 2(4):85-6, 2008.

Prescher, A. Anatomical basics, variations, and degenerative changes of the shoulder joint and shoulder girdle. Eur. J. Radiol., 35(2):88$102,2000$.

Rengachary, S. S.; Burr, D.; Lucas, S.; Hassanein, K. M.; Mohn, M. P. \& Matzke, H. Suprascapular entrapment neuropathy: a clinical, anatomical, and comparative study. Part 2: anatomical study. Neurosurgery, 5(4):447-51, 1979.

Romanes, G. J. Cunningham's Textbook of Anatomy. $12^{\text {th }}$ ed. New York, Oxford University Press, 1995. pp.30-2.

Sabanciogullari, V.; Kosar, M. I.; Erdil, F. H.; Çimen, M. \& Aycan, K. Insisura skapula morfometrisi. Cumhur. Univ. Tip Fak. Derg., 28(2):45-9, 2006.

Saha, S. \& Vasudeva, N. Morphometric evaluation of adult acromion process in North Indian population. J. Clin. Diagn. Res., 11(1):AC08AC11, 2017.

Soames, R. W. Skeletal System. In: Williams, P. L. (Ed.). Gray's Anatomy. $38^{\text {th }}$ ed. New York, Churchill Livingstone, 1995. pp.615$20,627-34$.

Taser, F. A. \& Basaloglu, H. Morphometric dimensions of the scapula. Ege Tip Derg., 42(2):73-80, 2003.

Taskınalp, O.; Akdere, H. \& Acıkalın, H. Acromion'un anatomik özelligi. Morfol. Derg., 9(1):22-3, 2001.

Ticker, J. B.; Djurasovic, M.; Strauch, R. J.; April, E. W.; Pollock, R. G.; Flatow, E. L. \& Bigliani, L. U. The incidence of ganglion cysts and other variations in anatomy along the course of the suprascapular nerve. J. Shoulder Elbow Surg., 7(5):472-8, 1998.

Urgüden, M.; Ozdemir, H.; Dönmez, B.; Bilbasar, H. \& Oguz, N. Is there any effect of suprascapular notch type in iatrogenic suprascapular nerve lesions? An anatomical study. Knee Surg. SportsTraumatol. Arthrosc., 12(3):241-5, 2004.

Voisin, L. J.; Ropars, M. \& Thomazeau, H. The human acromion viewed from an evolutionary perspective. Orthop. Traumatol. Surg. Res., 100(8 Suppl.):S355-60, 2014.

von Schroeder, H. P.; Kuiper, S. D. \& Botte, M. J. Osseous anatomy of the scapula. Clin. Orthop. Relat. Res., (383):131-9, 2001.

\section{Corresponding author: \\ Prof. Dr. Ozkan Oguz \\ Cukurova University \\ Faculty of Medicine \\ Department of Anatomy \\ 01330 Balcali - Adana \\ TURKEY}

Email : ozoguz@cu.edu.tr

Received: 03-04-2018

Accepted: 22-08-2018 